\title{
O JURISPRUDENCIALISMO DE ANTÓNIO CASTANHEIRA NEVES E O FUNCIONALISMO JURÍDICO
}

\section{Ivan Cláudio Pereira Borges ${ }^{1}$}

\section{Resumo}

A estrutura teórica do Jurisprudencialismo, proposta por Antônio Castanheira Neves, será o objeto da presente exposição. Trata-se de uma alternativa teórica para a realização do direito nos nossos dias. É melhor compreendida frente ao Normativismo Jurídico e ao Funcionalismo Jurídico, que são as duas grandes correntes jurídicas dominantes da teoria geral do direito. A primeira se revelou numa racionalidade ancorada no sistema de normas e no método interpretativo lógico-dedutivo do sistema, e a segunda que busca superar o formalismo normativista por meio da ênfase na instrumentalização integral do direito com vista ao atingimento de fins metajurídicos e maior efetividade do direito. A alternativa jurisprudencialista, por sua vez, envolve a consideração, primeiro, do ser humano como pessoa, que é, ao mesmo tempo, sujeito de direito e sujeito de deveres, com responsabilidades firmadas em um conteúdo axiológico construído. Acrescenta a dimensão da práxis, onde o indivíduo deve ser sempre percebido como sujeito comunitário. A problemática jurídica se estabelece neste sistema sempre com a conjugação axiológica comunitária, via legislação estabelecida, e o universo prático onde histórico e culturalmente o ser humano está integrado. A concepção de Direito e as categorias de inteligibilidade do Jurisprudencialismo também são expostas. Uma comparação ao Funcionalismo Jurídico, tendência atual identificada por Castanheira Neves, é apresentado como ponto de reforço de sua tese. Justifica-se a presente exposição frente a sinais de estresse do atual sistema jurídico. A metodologia empregada é teórico-crítica por meio de análise bibliográfica. Conclui-se pela possibilidade de adoção, ou pelo menos de discussão, do Jurisprudencialismo como pressuposto teórico-jurídico no Brasil.

Palavras-chave: Teoria Geral do Direito; Castanheira Neves; Funcionalismo Jurídico; Jurisprudencialismo; Normativismo.

\footnotetext{
${ }^{1}$ Professor de Filosofia do Direito e Direito Civil da Faculdade de Ciências Jurídicas e Sociais do DF - UNICEUB. Doutor em Direito pelo Instituto CEUB de Pesquisa e Desenvolvimento. E-mail: ivanclaudio56@gmail.com
} 


\section{INTRODUÇÃO}

A reforma constitucional do Judiciário empreendida nos idos de 2004 no Brasil teve como parâmetro possibilitar a celeridade e a acessibilidade da prestação jurisdicional com o objetivo geral de alcançar a realização do status democrático da sociedade e do indivíduo através da efetividade do serviço judiciário. Apesar deste grande empreendimento legislativo, manteve o legislador a determinação de propor novos projetos de lei que permitissem dar maior efetividade ao sistema judiciário.

Contudo, a melhoria dos serviços judiciários não decorre somente ou principalmente das transformações, atualizações, restruturações dos procedimentos de produção. O direito é concebido a partir de pressupostos teóricos, que estabelecem sua natureza, seus procedimentos de realização e seus objetivos. No conjunto de expressões do direito há uma racionalidade especificamente jurídica que determina a substância e a forma do direito. De tempos em tempos há uma mudança paradigmática nestes pressupostos, reorientando a trajetória jurídica.

Para Castanheira Neves, o Normativismo Jurídico foi um destes paradigmas que permaneceu por séculos, fruto de uma cosmovisão jurídica dependente da lógica aristotélica, depois também tomista, sobre textos juridicamente legitimados, e que passou a declinar de sua importância apenas no alvorecer da Aufklärung do século XVIII, retomada, em outros moldes, na pandectística alemã, e abandonada já no século XX com a linguistic turn e os questionamentos hermenêuticos, formulados com mais ênfase a partir de Gadamer.

O antigo paradigma foi superado em tempos mais recentes pelo Funcionalismo Jurídico, afirmou ele. Segundo Castanheira Neves, houve uma singular alteração na forma de pensar o direito, como também ocorreu noutras dimensões da experiência humana. Neste segundo caminho, o direito foi retirado de sua suposta posição autônoma no quadro das ciências, e relegado a um mero coadjuvante no processo de solução e regulação dos problemas sociais. Daí a cadência que segue uma nota sempre renitente na pauta jurídica, que é a da realização, ou da efetivação jurídica, seja por uma concepção crítica ou pragmática, de base marxista no primeiro caso, ou originado de expectativas realistas no segundo aspecto. Nem um e nem outro são parâmetros suficientes para os dias atuais. Por isso, propõe ele o Jurisprudencialismo como novo caminho.

Ao propor uma perspectiva diferenciada Castanheira Neves o faz pela diferenciação com duas outras concepções englobantes da teoria jurídica que a precedem, isto é, o Normativismo e o Funcionalismo Jurídico. Seu Jurisprudencialismo posiciona-se equidistante de ambos. Para que sua proposta possa ser melhor analisada faz-se necessária uma sucinta exposição dos marcos teóricos do direito pelos quais ele rejeita. Assim, será possível averiguar, inicialmente, se sua percepção dos posicionamentos precedentes são adequadas para, depois, apreciar a qualidade de sua tese. O Jurisprudencialismo será exposto neste texto de forma reduzida aos seus principais 
andaimes estruturais. A partir destes tentaremos aventar a possibilidade de aplicação prática de sua proposta no ambiente jurídico brasileiro.

A argumentação teórica do Jurisprudencialismo encontra-se exposta em vários textos publicados por Castanheira Neves e não em um único destinado à sua exposição. ${ }^{2}$ Há, contudo, um texto produzido no Brasil, por ocasião da visita de Castanheira Neves, Fernando José Bronze, José Manuel Aroso Linhares, e Ana Margarida Simões Gaudêncio, também professores na faculdade de Direito de Coimbra, à Faculdade de Direito de Salvador, quando estes e outros expositores brasileiros se detiveram em expor com mais detalhes o assunto. $\mathrm{O}$ livro teve reduzida tiragem e não está mais disponível no mercado, podendo ser consultado na rede internacional de computadores (internet). ${ }^{3}$ Menção explícita ao Jurisprudencialismo aparece sempre ao final de alguns textos. Dentre estes, $O$ direito hoje e com que sentido? Isto pode ser melhor percebido na coletânea de sua obra, a Digesta.

É importante advertir o leitor, sobretudo aquele que se aventurar a ler Castanheira Neves em sua fonte primária, que o Jurisprudencialismo é apresentado pelo autor por meio de comparações e antíteses com o Normativismo Jurídico e, mais ainda, com o Funcionalismo Jurídico. O funcionalismo jurídico, segundo ele, sucedeu ao normativismo, que perdeu seu espaço na razão teórico-jurídica no século XX. O funcionalismo jurídico é multifacetário, procurando sempre novas máscaras para materializar-se no cenário jurídico.

\section{O JURISPRUDENCIALISMO DE ANTÓNIO CASTANHEIRA NEVES}

Pois bem, justificado o motivo acadêmico-prático do estudo que ora empreendemos, permita-nos olhar o Jurisprudencialismo em seus fundamentos, pilares e vigas. A começar pelos seus pressupostos, que se equilibram num triplo ponto de partida: a) recompreensão antropológica; b) novo entendimento da práxis e da razão prática; c) perspectiva particular da consideração da problemática jurídica. Depois, na identificação das características do Jurisprudencialismo mediante a resposta a três perguntas: 1) Qual a concepção do direito para o Jurisprudencialismo?; 2) A que categorias de inteligibilidade e a que tipo de racionalidade corresponde o Jurisprudencialismo?; 3) Qual seu modelo metodológico jurídico que postula?

\footnotetext{
${ }^{2}$ NEVES, António Castanheira. Teoria do Direito. Lições proferidas no ano lectivo de 1998/1999. Coimbra: Universidade de Coimbra, 1998; ___ Digesta, Coimbra: Coimbra Editora, 1995, volume 2º, III, 2.; , Metodologia Jurídica. Problemas Fundamentais. STVDIA IVRIDICA I, Coimbra: Coimbra Editora, 1993; O Direito hoje e com Que Sentido? O problema actual da autonomia do direito. Lisboa: Instituto Piaget, 2002. prático. In: Digesta, Coimbra: Coimbra Editora, 1995, vol. 1º, pp 311-336.

${ }_{3}$ COELHO, Nuno M. M. Santos, e SILVA, Antônio Sá da (orgs.). Teoria do Direito. Direito interrogado hoje - O jurisprudencialismo: uma resposta possível? Estudos em homenagem ao Doutor Antonio Castanheira Neves. Salvador-Bahía: Faculdade Baiana de Direito, 2012.
} 


\section{PRESSUPOSTOS DO JURISPRUDENCIALISMO - O HOMEM PESSOA}

Iniciemos com o primeiro pressuposto do Jurisprudencialismo: uma recompreensão antropológica, na busca pela construção da figura jurídica do Homem-Pessoa.

O direito é antes de tudo o produto cultural do espírito humano. Origina-se com o homem e se destina ao ser humano. Portanto, nada mais lógico Castanheira propor que o direito seja compreendido pelo próprio ente que lhe dá sentido de existência, ou seja, o ser humano. Mas o que é este ser humano? Antes de tudo, é um ser único e, portanto, com dignidade de existência. Este ser único ocupa um lugar próprio no qual o direito deve proteger. Em suas palavras, definir o direito a partir da "recompreensão antropológica", ou seja ver o ser humano com dignidade pela lente do direito; ver o homem jurídico inescapavelmente pela complexidade axiológica que nele se encerra. Isto é, uma recuperação da compreensão de como e o que propriamente somos como seres humanos, e uma recuperação da compreensão das exigências do compromisso de coexistência com os demais semelhantes.

Numa análise específica desta relação homem-coletividade, Castanheira esclarece sobre a imagem atual do homem no universo prático:

"Deixou ele de ser homo juridicus, sem voltar a ser homo institucionalis - passou a ser homo socialis. E isto significa que o homem se reconheceu a viver num meio real e pela mediação concreta de um mundo humano não conhecido pela filosofia prática pré-moderna e que o individualismo moderno-iluminista também não considerou - a sociedade...que não se confunde com a polis e a civitas, nem com a comunitas medieval e se dintingue também do Estado...pois se trata da colectivizante e horizontal realidade da nossa meramente associativa interrelacional e anônima coexistência económico-tecnicamente estruturada." ${ }^{4}$

Por vezes na história humana o homem teve de aprender a olhar para o ser humano como olha para si mesmo. Para não irmos muito atrás, bastam alguns episódios gerais. Na Antiguidade, já no final do período Clássico para o Pós-Clássico do direito romano, as influências do humanismo da Escola Estóica, das boas novas do Cristianismo ainda nascente, criaram um ambiente revolucionário que rompeu, em muitos aspectos, com a desumanidade daqueles tempos. Mesmo assim, novamente a opressão se manifestaria pelo veículo religioso, e somente com os processos de ruptura nas artes primeiro, com a Renascença e o Humanismo, depois na religião com a Reforma Religiosa do século XVI, e as revoluções populares, das quais a mais significativa foi a Francesa, em 1789, produziram novo impacto e nova chamada do homem para a responsabilidade de ver no outro o direito que a si mesmo requeria.

Tempos depois, na agitação dos povos europeus frente à frustração com o Liberalismo, e que se seguiu o desencantamento do mundo, por duas vezes assistiu-se à desconsideração do ser humano por sua própria espécie.

\footnotetext{
${ }^{4}$ A imagem do homem no universo prático. In: Digesta, Coimbra: Coimbra Editora, 1995, vol. 1º, pp. 331-332.
} 
Somente no segundo pós-guerra na Europa, o homem foi reconvocado a olhar para si mesmo no espelho da desgraça que para ela contribuíra, e a reprogramar-se para olhar o outro com os olhos da humanidade. Os direitos foram denominados de "humanos" e dava-se início a uma busca implacável contra a intolerância e os radicalismos que, registre-se, ainda não acabou, porque como Fênix, se recompõe e surge nas mentes de bestas-feras, travestidos de humanos, pelo mundo na atualidade.

Essas sucessivas experiências agregaram ensinamentos e postulados que não poderiam ser desprezados na formulação de uma teoria do direito para a atualidade. O primeiro pressuposto do Jurisprudencialismo de Castanheira Neves é extraído de sua compreensão filosófica e prática, maturada pela evolução do conceito e prática do ser humano como pessoa ${ }^{5}$. Recompreensão que deve ser feita a partir de dois elementos: de como e o que propriamente somos como seres humanos, e das exigências do compromisso de coexistência. Não há como simplificar o direito tendo em vista a característica multifacetária do ser humano. É pessoa com dignidade, mas ao mesmo tempo é plenamente indivíduo, sem poder ser individualista, antes comunitarista.

Em outras palavras, o ser humano no Jurisprudencialismo é uma pessoa, sujeito de direito e inescapavelmente sujeito de deveres, o que implica que o ser humano nunca pode ser apenas objeto de atenções do direito, mas sujeito ao mesmo tempo dos direitos que invoca para si. O ser humano é uma entidade antropológica que sobrevive axiologicamente. "O homem-pessoa e a sua dignidade é o pressuposto decisivo, o valor fundamental e o fim último que preenche a inteligibilidade do mundo humano do nosso tempo.. ${ }^{6}$ Uma axiologia compartilhada, que se submete à construção intersubjetiva dos interesses comunitários, e que desfruta do respeito aos limites de sua individualidade. Por uma palavra, existência autônoma somada à existência comunitária. "O que deve, no entanto, entender-se nas suas verdadeiras dimensões. A pessoa é um ser pessoal e simultaneamente um ser social. Se se aliena ao perder-se ou ao degradar-se na sua pessoalidade, também não se realiza nem vem à epifania se si própria sem a mediação comunitária." ?

Para Castanheira Neves, recompreender o homem, o ser humano, como pessoa com dignidade, o que muito se reclama nos dias de hoje, é uma necessidade que evoca inevitavelmente a axiologia como definidor desta pessoa. Não há como evitar esse ser humano com dignidade, porque ele é participante do "reino dos fins", do mundo dos valores. Isto, segundo ele, concede sentido e fundamento ao comprometimento coletivo. "E, assim, se o 'eu pessoal' depara no seu horizonte dialéctico de realização com um 'eu social' ou comunitário, sem que um ao outro se reduzam também à comunidade, que imediatamente se afirma neste segundo 'eu', não lhe será lícito recusar-se à mediação para o cumprimento daquele primeiro, na sua concreta personalização...”; "Nem é outro o

\footnotetext{
${ }^{5}$ A imagem do homem no universo prático. In: Digesta, Coimbra: Coimbra Editora, 1995, vol. 1º, pp. 319-331.

${ }^{6}$ CASTANHEIRA NEVES, António. O Direito hoje e com Que Sentido? O problema actual da autonomia do direito. Lisboa: Instituto Piaget, 2002, p. 69.
} 
sentido e o exacto fundamento dos direitos do homem e dos direitos fundamentais." Em termos ainda mais radicais, Castanheira chama a atenção para a impraticabilidade do direito sem esta relação indivíduo-comunidade, ao dizer: "Ou estamos condenados a uma existencial incomunicabilidade comunitária e o direito deixa de ter sentido para a Existência como tal, ou a comunicação e integração comunitárias se revelam existencialmente autênticas e o direito encontra na própria Existência o seu fundamento."

Sem a dignidade como caracterizadora do ser humano não há possibilidade de se construir uma sociedade comunitarista. A dignidade já foi exigida no pensamento de Kant mediante o respeito ${ }^{10}$, e no idealismo hegeliano pelo reconhecimento. Ao contrário de resistências a respeito, que colocam a dignidade como entidade ontológica, Castanheira defende que se trata de uma categoria axiológica.

Os focos de resistência seriam as concepções substancialistas da Pessoa em Boécio, ou substancialista do ser do Logos ou que possui o Logos, em Tomás de Aquino, ou ainda a concepção pragmático-transcendental, referente à comunicação, em Karl-Otto Apel, ou referente ao discurso de Adela Cortina.

Importante contribuição a respeito da definição do fundamento da dignidade da pessoa humana nos trouxe Antonio Junqueira de Azevedo, professor da Faculdade de Direito da USP, publicado em 2002, na revista dessa instituição. ${ }^{11}$

O conteúdo a respeito da significação da expressão "dignidade da pessoa humana", disse ele, produziu pelo menos duas concepções. A concepção insular e ainda dominante da pessoa humana, fundada no homem como razão e vontade, leva, segundo ele, ao entendimento da dignidade humana como autonomia individual, ou autodeterminação. Ontologicamente, a concepção insular estabelece uma diferenciação entre o ser humano e a natureza. Diferentemente, outra concepção, a concepção própria de uma nova ética, fundada no homem como ser integrado à natureza, "[...] cuja nota específica não está na razão e na vontade...e sim, em rumo inverso, na capacidade do homem de sair de si, reconhecer no outro um igual[...]" ${ }^{\prime 2}$.

Vê-se, na abordagem feita pelo ilustre professor que o assunto se restringe a um ponto de vista ontológico e antropológico para cada uma das opções teóricas sobre a dignidade da pessoa humana. Castanheira inova ao trazer a percepção axiológica como elemento da visão jurídica sobre o tema. Não é uma axiologia

\footnotetext{
${ }^{7}$ Idem, ibidem.

${ }^{8}$ Idem, pp. 69-70.

${ }^{9}$ CASTANHEIRA NEVES, António. O papel do jurista no nosso tempo. In: Digesta. Coimbra: Coimbra Editora, 1995, p. 20.

${ }^{10}$ WALDRON, Jeremy. Citizenship and Dignity. In: Public Law and Legal Theory Research Paper Series, New York University School of Law. January 2013. Working Paper 12-74. Kant menciona a dignidade humana nos dois sentidos conhecidos. Tanto o ligado ao sentido de dignidade hierárquica, como o que está vinculado à igualdade.

${ }^{11}$ AZEVEDO, Antonio Junqueira de. Caracterização jurídica da dignidade da pessoa humana. In: revista USP, São Paulo, n. 53, p. 90-101, março/maio 2002.

${ }^{12}$ AZEVEDO, Antonio Junqueira de. Caracterização jurídica da dignidade da pessoa humana. In: revista USP, São Paulo, n. 53, p. 90-101, março/maio 2002, p. 92.
} 
distante dos problemas concretos, no idealismo de um direito que se encerra nas normas, mas inova por requerer que a prática jurídica, a concretização de que nos falou Miguel Reale em seu Culturalismo (Experiência Jurídica), se faça com bases axiológicas, em que são elementos componentes o indivíduo e a comunidade.

Este reconhecimento da dignidade ética da pessoa implica na exigência de fundamento para todas as pretensões, porque envolve a intersubjetividade da coexistência, ressaltou o mestre de Coimbra.

Com este primeiro pressuposto, observa-se que o Jurisprudencialismo tem na consideração axiológica do ser humano individual, mas não individualista, e do ser humano coletivamente considerado, isto é, com responsabilidade e não apenas com direitos, o elemento fundamental da razão jurídica. Com esta premissa, o direito não pode ser pensado tão somente como instrumento ou como pretexto de objetivos referentes a outros reguladores funcionais, como a economia ou planejamentos tecno-sociais. Exemplo desta tendência é a Law and Economics, ou Análise Econômica do Direito. Por esta via funcionalista não se vê o ser humano com valor intrínseco, axiologicamente considerado, mas apenas como racionalmente capaz de gerir seus interesses individuais em meio aos interesses que emergem das relações econômicas. Se assim for, o direito será moldado para atender projetos macro e micro econômicos, e a "axiologia" será entendida na base do atendimento ao bemestar meramente econômico do indivíduo e do grupo.

\section{PRESSUPOSTOS DO JURISPRUDENCIALISMO - O NOVO ENTENDIMENTO DA PRAXIS}

O segundo pressuposto do Jurisprudencialismo localiza-se no novo entendimento da práxis e da razão prática. Castanheira foge das compreensões extremas, tanto do pensamento clássico, com sua base aristotélica, cujo sentido último estaria vinculado a uma ordem ontológico-metafísica, o que sustentou por longo tempo o jusnaturalismo clássico, como o extremismo originado pelas novas perspectivas do homem moderno, reassumindo a subjetividade e reivindicando a autonomia-liberdade.

Em um movimento pendular, o Jurisprudencialismo pressupõe como manifesta a intersubjetividade histórico-social. Isto é, a práxis ocorre tanto num contexto comunitário culturalmente significante como pela abertura de uma dialética a uma questão concreta, problemática e constituinte. Em outras palavras, práxis que exige interação de sujeitos pessoais, inserida sempre em condição comunitária que se supera. ${ }^{13}$

Além disto, sugere ele que o sentido da filosofia prática deve ser restaurado, pois por ela se dará a possibilidade da própria práxis. Vale-se ele da atualidade desta restauração de sentido em muitas áreas do saber,

\footnotetext{
${ }^{13}$ NEVES, António Castanheira. Teoria do Direito. Lições proferidas no ano lectivo de 1998/1999. Coimbra: Universidade de Coimbra, 1998, p. 81.
} 
como a histórico-cultural, a filosófico-ética, filosófico-política, axiológicas, discursivo-racionais, reveladas por Mandred Riedel na obra que menciona justamente esta reabilitação, Rehabilitierung der praktischen Philosophie, de 1974. Também estão com ele nesta compreensão Hans Jonas, quanto ao problema atual da ética, o teólogo Hans Küng, o jurista Karl Otto-Apel, Jürgen Habermas, in Erläuterungen zur Diskurssethik (Comentários à Ética do Discurso), Levinas, Totalidade e infinito, Paul Ricouer, Soi-même comme au autre. Lembra que tal restauração da razão prática tentou-se também no direito, através das obras de Kryele, Alexy, Otta Weinberger, Arnio e Peczenik.

Somando, portanto, à intersubjetividade histórico-social, numa compreensão culturalmente comunitária, possibilitada pela filosofia prática e sua razão prática, desenvolvida e requerida nestas últimas décadas, adiciona o elemento da recente discussão do sentido da justiça em confronto com a perspectiva social do utilitarismo, em John Rawls, sobretudo.

\section{PRESSUPOSTOS DO JURISPRUDENCIALISMO - A PROBLEMÁTICA JURÍDICA}

Terceiro e último pressuposto é a perspectiva particular da consideração da problemática jurídica. Dá-se esta pela conjugação de dois opostos, ou de "duas perspectivas contrárias". Por um lado, a perspectiva da sociedade. No chamado "direito da sociedade" o que juridicamente é relevante é a lex, seja sob a forma de norma, ou de imperativo, ou de regra, bem como a "programação social através dela".

Por outro lado, a perspectiva do ser humano, que na ênfase de Castanheira, é a do homem-pessoa, o "[...] homem concreto que vive os acontecimentos práticos e convive na inter-acção histórico-social[...]"14. Aqui o juízo prático convoca uma normatividade axiologicamente constituída. O "homem-pessoa" é tanto sujeito de autonomia como sujeito de responsabilidade. Sua liberdade e dignidade devem ser reconhecidas na base de seus deveres e não somente dos direitos que possui ou que pretende ver reconhecido.

Em outros termos, Castanheira pressupõe que certa situação jurídica, um caso qualquer sobre o qual, em tese, incide uma norma jurídica, o que está em análise, num primeiro momento é a "heteronomia macroscópica da sociedade" ${ }^{15}$. Isto é, o caso encontra-se submetido à estruturação, à regulação e à organização global da sociedade. Mais ainda, o caso é problematizado num contexto cultural, político e social. Desta maneira, as questões jurídicas devem pressupor inicialmente um contexto macroscópico da sociedade, por onde surgiu a questão em debate judicial com todos os valores implicados.

\footnotetext{
${ }^{14}$ NEVES, António Castanheira. Teoria do Direito. Lições proferidas no ano lectivo de 1998/1999. Coimbra: Universidade de Coimbra, 1998, p. 85.
} 
Pressupõe também dedutivamente que do geral, ou seja, deste ambiente macro social, o direito pode ser exigido pelo homem concreto, que vivencia todo o contexto que envolve o caso. O indivíduo é parte da sociedade, esta defende a preservação de seus direitos privados, conquanto não sejam mais do que os dos outros. Dentro desta heteronomia macroscópica o cidadão pode reivindicar o que, aparentemente, é seu.

A diferença entre estas duas perspectivas também se dá pelo olhar normativo, em que pela lente macroscópica da sociedade o relevante é a lei - lex - como norma, imperativo ou regra, bem como a programação social que a sociedade busca por ela. Quanto ao olhar do ser humano em sua concretude jurídica, o caso deve ser tratado por uma axiológica normatividade convocada pelo juízo prático, em que ele possa se ver reconhecido. Isto é, uma axiologia que lhe faça sentido no contexto geral da consciência jurídica que lhe envolve. Dito de outra forma, "Duas perspectivas diferentes cujos referentes últimos são, na verdade, a sociedade e as suas exigências jurídico-funcionais, para a primeira, e o homem e a postulação do seu direito, para a segunda." ${ }^{16}$.

\section{AS CARACTERÍSTICAS DO JURISPRUDENCIALISMO - A CONCEPÇÃO DO DIREITO}

Unindo as premissas é possível perceber as seguintes características do Jurisprudencialismo. O direito é um "[...] ]axiológico-normativo fim em si[...]" 17. O direito só o é como tal se possui uma perspectiva de valoração, justificada na inter-relação necessária dos seres humanos, somada a um fundamento de validade, que é a lex, e sempre no universo prático, isto é, das realizações, dos problemas e das soluções.

Ao rejeitar a racionalidade que coloca o Direito como objeto e aquela que o torna mero instrumento (funcionalismo técnico ou estratégico de regulação social), propõe o Jurisprudencialismo tratar o Direito numa compreensão prático-normativa como validade axiológico-normativa. Ou seja, o Direito é a norma em evolução concreta e axiologicamente considerada. Dito pelo próprio Castanheira, "convoca uma axiologia, postula a intenção de um normativo compromisso prático em que a racionalidade não é dada por um teórico universal sistemático, mas por uma prática fundamentação normativa material." ${ }^{18}$

O Direito para o Jurisprudencialismo não abandona os concretos problemas práticos, os conflitos e as controvérsias prático-problematicamente concretas, como faz o Funcionalismo Jurídico, ao olhar apenas

\footnotetext{
${ }^{15}$ NEVES, António Castanheira. Teoria do Direito. Lições proferidas no ano lectivo de 1998/1999. Coimbra: Universidade de Coimbra, 1998, p. 85.

${ }^{16}$ NEVES, António Castanheira. Teoria do Direito. Lições proferidas no ano lectivo de 1998/1999. Coimbra: Universidade de Coimbra, 1998, p. 86.

${ }^{17}$ Idem, p. 88.

${ }^{18}$ NEVES, António Castanheira. Teoria do Direito. Lições proferidas no ano lectivo de 1998/1999. Coimbra: Universidade de Coimbra, 1998, p. 87.
} 
macroscopicamente a questão jurídica, sob o olhar da realidade social. Para este último, o direito é apenas um elemento de organização e de administração e direção geral da sociedade. O Direito não é só objeto normativo que esteja à disposição de uma pura racionalidade para o exercício de uma determinação estritamente racional ou instrumental. O Direito é uma composição de norma e valor, e sua validade encontra-se fundamentada neste valor que está no universo prático. Via de consequência, o Direito assume-se como valor referente à intersubjetividade, a relação entre as pessoas na vida prática do dia-a-dia.

\section{AS CARACTERÍSTICAS DO JURISPRUDENCIALISMO - CATEGORIAS DE INTELIGIBILIDADE E TIPO DE RACIONALIDADE CORRELATIVA}

As categorias de inteligibilidade do Jurisprudencialismo são duas e fundamentais: o sistema e o caso. $\mathrm{O}$ primeiro num sentido prático-normativo específico, e o segundo como problema jurídico concretamente decidendo.

\section{O sistema}

A inteligibilidade ou a maneira pela qual se entende o direito leva em consideração, em primeiro lugar, o sistema jurídico, que Castanheira menciona simplesmente como "sistema", para se referir apenas às opções axiológicas. Isto é, a racionalidade do Jurisprudencialismo se desenvolve nas "opções, postulados e princípios, perante os quais as normas não serão mais do que suas expressões objectivamente particulares e em função dos quais estas[...]se hão-de mostrar jurídico-normativamente fundadas[... ”]19. Há para o Jurisprudencialismo uma unidade sistêmica, que se dá na utilização de todo o aparato material, ou por suas palavras "unidade de totalização normativa do sistema", que serve para expressar as "opções axiológicas".

A realização do direito conjuga os valores, os princípios, e os critérios normativos numa compossibilidade. Mais especificamente, Castanheira coloca sob o dossel das "opções axiológicas" quatro elementos que ele reputa constitutivos destas. São estes: os "princípios positivos, transpositivos, e suprapositivos", as "normas prescritas numa opção político-estratégica", a "jurisprudência" ou "momento da objectivação e estabilização de uma já experimentada realização problemático-concreta do direito" e, por fim, a "dogmática" ou "doutrina jurídica", sustentada apenas "na sua própria racionalidade fundamentada". ${ }^{20}$

\footnotetext{
${ }^{19}$ Idem, pp. 88-89.

${ }^{20}$ Discussões pormenorizadas do ponto de vista sistêmico do Jurisprudencialismo podem ser observadas, pela própria indicação do mestre coimbrão, na Unidade do sistema jurídico, in Digesta, volume 2º, III, 2, p. 109 e seguintes.
} 


\section{O CASO}

Leva em consideração também o que Castanheira Neves chama de "caso". Primeiramente, "sistema" e, agora o "caso". Ou seja, o caso jurídico. O caso jurídico, como bem colocou, é sempre um problema novo. Ou seja, "é um problema jurídico (de direito) numa certa situação histórico-social." ${ }^{21}$ Não há como escapar do fato de que "um problema é[...] sempre o perguntar[...] algo[...] a algo[...]por algo." ${ }^{22}$, como explicitou Heidegger, invocado por Castanheira. A "atitude metodológica" perante o problema jurídico, "será sempre a mesma, qualquer que venha a ser a orientação do seu resultado[...].”ㄹ Isto é, a racionalidade metodológica é uma posição autônoma perante o problema que é sempre novo. E a razão é esta, "será impossível deduzir de um saber anterior a posição do problema, tanto no caso de ela nos vir a revelar um problema novo, como no caso de ser a reposição de um tipo de problema já antes posto, pois é sempre como problema que em concreto o assumimos."24

O "caso" é um problema jurídico e possui esta marca na gênese do "projecto axiológico-normativo que se constitui na vida histórica de uma determinada comunidade." 25 Há, por certo, a construção de uma "consciência jurídica geral de uma certa época." ${ }^{26}$, ou em outras palavras, de "um pré-saber", que se materializa nas "normas positivas", "nos precedentes judiciais", "nas elaborações doutrinais", mas que, apesar disto, "não poderá nunca dispensar uma autónoma posição do problema jurídico do caso decidendo." ${ }^{27} \mathrm{Ou}$ seja, haverá sempre uma novidade problemática e problematizante a ser enfrentada que requererá a garimpagem do sentido axiológico contido na consciência jurídica geral.

\section{O TIPO DE RACIONALIDADE QUE CORRESPONDE JURISPRUDENCIALISMO} $\mathrm{AO}$

Às duas categorias de inteligibilidade soma-se também na caracterização do Jurisprudencialismo o tipo de racionalidade que the corresponde. Ou melhor, a índole de racionalidade que nele está implicado.

A racionalidade jurisprudencialista "...é material e não tão-só procedimental, e não apenas hermenêutica mas praxística e concretamente decisória.... ${ }^{28}$. Explica-se. O Jurisprudencialismo exclui as racionalidades tanto

\footnotetext{
${ }^{21}$ NEVES, António Castanheira. Metodologia Jurídica. Problemas Fundamentais. STVDIA IVRIDICA I, Coimbra: Coimbra Editora, 1993, p. 159.

${ }^{22}$ Idem, p. 159.

${ }^{23}$ Idem, p. 160.

${ }^{24}$ Idem, p. 160.

${ }^{25}$ Idem, p. 161.

${ }^{26}$ Idem, p. 161.

${ }^{27}$ Idem, p. 161.

${ }^{28}$ Idem, p. 77.
} 
puramente lógica como teorética, o que situa a racionalidade jurisprudencialista no domínio da racionalidade prática. $^{29}$

A pura e simples índole material de uma racionalidade jurídica não subsiste mais em seus fundamentos. A lacunosidade e abertura, a indeterminação normativa, a vaguidade linguística, isto e muito mais, solaparam o fundamento material deste tipo de racionalidade. Admitidas as imprecisões da materialidade a opção da racionalidade foi se refugiar na ampla autonomia constitutiva da mediação problemático-decisória, tanto nos critérios como em relação às possibilidades judicativas. Isto implicou, como se sabe, que a decisão judicial é sempre o resultado de uma opção, a reforçar aí a tão recente teoria da decisão.

O ocaso provocou a aurora da tópica-retórica de Viehweg e da prática argumentativa de Perelman, o que impôs a reconsideração da intencionalidade material na racionalidade jurídica em outros termos pelo Jurisprudencialismo. Mas como chama a atenção Castanheira, tal imposição não empurrou a racionalidade jurídica do Jurisprudencialismo para a racionalidade hermenêutica.

Primeiro, porque o que resulta da racionalidade jurídica "...é de natureza praxístico-decisória e não simplesmente significativo-compreensiva do pensamento jurídico.”. E o motivo é que “...a intenção e as exigências regulativas deste pensamento não se cumprem numa 'doutrina de um correcto compreender", citando Canaris ${ }^{30}$, “...mas na doutrina de um justo decidir." ${ }^{31}$ Além disto, a fraqueza da exclusiva racionalidade hermenêutica se verifica também no fato de que "...entre os fundamentos ou os critérios e a decisão concreta intervém a mediação judicativa com sua específica dimensão problemática e de uma particular autonomia constitutiva." ${ }^{32}$ Atenta também contra a racionalidade hermenêutica “...a intencionalidade normativa da decisão judicativa.", pois há um caráter simplesmente especificante da applicatio ou da "concretização" hermenêuticas. ${ }^{33}$ E, por fim, "...não se trata de conhecer o sentido de uma significação cultural numa concreta situação de compreensão e em referência a esta, ou de reintegrar o caso decidendo surgido dessa situação no sistema global da validade significante, mas de ajuizar decisoriamente do mérito normativo do problema prático-concreto desse caso na perspectiva da fundamentante validade dogmaticamente objectivanda." ${ }^{34}$

\footnotetext{
${ }^{29}$ NEVES, António Castanheira. Metodologia Jurídica. Problemas Fundamentais. STVDIA IVRIDICA I, Coimbra: Coimbra Editora, 1993, p. 71.

${ }^{30}$ NEVES, António Castanheira. Metodologia Jurídica. Problemas Fundamentais. STVDIA IVRIDICA I, Coimbra: Coimbra Editora, 1993, p. 76.

${ }^{31}$ NEVES, António Castanheira. Metodologia Jurídica. Problemas Fundamentais. STVDIA IVRIDICA I, Coimbra: Coimbra Editora, 1993, p. 76.

32 NEVES, António Castanheira. Metodologia Jurídica. Problemas Fundamentais. STVDIA IVRIDICA I, Coimbra: Coimbra Editora, 1993, p. 76.

${ }^{33}$ NEVES, António Castanheira. Metodologia Jurídica. Problemas Fundamentais. STVDIA IVRIDICA I, Coimbra: Coimbra Editora, 1993, p. 76.

${ }^{34}$ NEVES, António Castanheira. Metodologia Jurídica. Problemas Fundamentais. STVDIA IVRIDICA I, Coimbra: Coimbra Editora, 1993, p. 76.
} 
E se a racionalidade jurídica do Jurisprudencialismo é praxística não seria teleológica? Na opinião de Castanheira Neves, “...a decisão concreta não pode aceitar-se agora tão-só como meio técnico para lograr quaisquer fins pretendidos, terá de manifestar um conteúdo prático com critério teleológico, ou em que os "fins" sejam intenções práticas a sustentarem juízos práticos." ${ }^{35}$ E não pode ser uma teleologia ontológica, ou a da subjetividade moderna, pois em ambos os casos, disse ele, “...o decidir teleológico refere uma validade e um decidir.

Em síntese, nas palavras de Castanheira Neves, a racionalidade do Jurisprudencialismo implica em quatro dimensões: uma validade pressuposta, que se objetiva numa dogmática, e uma concreta problematização praxística a exigir uma mediação judicativa. As duas primeiras se manifestam num sistema normativo, e as outras duas são convocadas por um problema prático. ${ }^{36}$

\section{O MODELO METODOLÓGICO}

De tudo o que foi visto acerca do Jurisprudencialismo, "[...] ] direito só o temos verdadeiramente, ou autenticamente como tal, com a instituição de uma validade e não como mero instrumento social de satisfação de interesses ou de necessidades." ${ }^{37}$

Há nitidamente no Jurisprudencialismo um recomeço, uma tentativa de renovar a confiança e esperança na razão jurídica como uma das vias democráticas da sociedade politicamente organizada. As desconfianças que pairam de tempos em tempos simpatizam agora com as mágicas soluções do funcionalismo.

O próximo item de nossa exposição dará ênfase ao funcionalismo jurídico identificado por Castanheira Neves. Como já se disse anteriormente, no início de nossa exposição, a compreensão do Jurisprudencialismo é nos dada sempre por Castanheira Neves em comparação ao Normativismo Jurídico e, sobretudo, ao Funcionalismo Jurídico. É preciso, no entanto, que se separe a antiga discussão do funcionalismo no Direito originada na década de sessenta, do século XX, com a compreensão feita pelo doutor de Coimbra.

\section{FUNCIONALISMO E FUNCIONALISMO JURÍDICO}

Nos idos da década de sessenta do século vinte estudos jurídicos sobre funcionalismo no ambiente jurídico eram recorrentes, tanto que houve uma sobreposição de significados, oscilando entre o funcionalismo no

\footnotetext{
${ }^{35}$ NEVES, António Castanheira. Metodologia Jurídica. Problemas Fundamentais. STVDIA IVRIDICA I, Coimbra: Coimbra Editora, 1993, p. 77.

${ }^{36}$ NEVES, António Castanheira. Metodologia Jurídica. Problemas Fundamentais. STVDIA IVRIDICA I, Coimbra: Coimbra Editora, 1993, p.79.

${ }^{37}$ Idem, p. 79.
} 
sentido sistêmico, finalístico ou instrumental. ${ }^{38}$

O funcionalismo parece ser uma decorrência do formalismo, um irmão mais jovem deste; seu complemento necessário e uma forma de corrigi-lo. ${ }^{39}$ Mais do que isto, significa, segundo alguns, uma fórmula para sua sobrevivência..$^{40} \mathrm{O}$ funcionalismo identificado no Direito descreve a forma pela qual a flexibilização e a modernização do direito formal tomam lugar a fim de dar uma solução prática aos problemas da sociedade, em reação ao incremento de um ambiente social complexo composto de interesses conflitantes.

Por outro lado, o funcionalismo jurídico surgiu como movimento anti-formalista nos Estados Unidos da América do Norte, após a segunda década do século XX, mais especificamente, após 1925, por uma geração de teóricos do direito, sendo os mais importantes Holmes, Pound e Cardozo. ${ }^{41}$ Estes autores deixaram de se posicionar frontalmente contra o formalismo jurídico e propuseram, ao invés, uma política funcionalista orientada por razões afirmativas do direito, que veio a se tornar a moderna ortodoxia jurídica. ${ }^{42}$

O direito passou a ser um ramo da ciência política, tendo como principal objetivo atender à soma dos interesses de indivíduos e grupos sociais. ${ }^{43}$ Como esclarece Thomas Grey, isto não significa que os valores jurídicos e a racionalidade formal deixaram de ser importantes, mas somente que os julgadores tiveram que, a partir de então, justificar o peso dado às considerações formais em termos de política substantiva, num avanço aos valores sociais tais como a acessibilidade, a estabilidade e a previsão das normas que orientam a ação estatal, e sem desvincular as decisões judiciais da lei pertencente ao ordenamento jurídico. ${ }^{44}$

Desde seu surgimento, o funcionalismo jurídico mudou. Alterou o foco de sua atuação. O motivo seria talvez para acomodar o direito às necessidades político-econômicas de salvamento do Welfare State. ${ }^{45} \mathrm{O}$ neofuncionalismo define a regra do direito e do Estado mediante uma simples exigência, tão sutil como comprometedora, que é a facilitação de suas molduras jurídicas em prol da autonomia individual. ${ }^{46} \mathrm{O}$ funcionalismo jurídico caracterizou-se então pela regra geral da produção de normas jurídicas orientadas a políticas públicas e a decisões judiciais que atendessem a programas ambiciosos de engenharia social através da lei.

\footnotetext{
${ }^{38}$ MICHAELS, Ralf. The functionalism of legal origins. (October 1, 2011). DOES LAW MATTER? ON LAW AND ECONOMIC GROWTH, 21-39 (100 Ius Commune Europaeum, Michael Faure \& Jan Smits eds., 2011). Available at SSRN: https://ssrn.com/abstract=2240928. Acess: October, 27, 2017.

${ }^{39}$ Peer Zumbansen. Law After the Welfare State: Formalism, Functionalism and the Ironic Turn of Reflexive Law, In Comparative Research in Law \& Political Economy, 13/2008, vol 4, n. ${ }^{\circ}$ 03, p. 14.

${ }^{40}$ Idem, p. 14.

${ }^{41}$ Thomas Grey. The New Formalism. In: Stanford Public Law and Legal Theory Working Paper Series, n 4, 1999, p. 9

${ }^{42}$ Idem, 9.

${ }^{43}$ Idem, p. 10.

${ }^{44}$ Idem, p. 11.

${ }^{45}$ Peer Zumbansen. Law After the Welfare State: Formalism, Functionalism and the Ironic Turn of Reflexive Law, In Comparative Research in Law \& Political Economy, 13/2008, vol 4, n. ${ }^{\circ}$ 03, p. 6.

${ }^{46}$ Peer Zumbansen. Law After the Welfare State: Formalism, Functionalism and the Ironic Turn of Reflexive Law, In Comparative Research in Law \& Political Economy, 13/2008, vol 4, n. ${ }^{\circ}$ 03, p. 6.
} 
O novo funcionalismo jurídico enfatiza a ameaça aos valores da liberdade de mercado e da competição pela crescente intervenção do Estado nos interesses particulares. Para tanto, emprega instrumentos teóricos que buscam modos alternativos de normatização, com a finalidade de traduzir a generalidade ou a abstração legal para um contexto e formas de erudição que permitam mais diretamente a regulação sócio-legal. ${ }^{47}$

Para Ralf Michaels, o funcionalismo instrumental possui uma ênfase normativa, em que as instituições seriam vistas como ferramentas, introduzidas pelos tomadores de decisão para resolver determinados problemas ou alcançar determinados objetivos. Este tipo de funcionalismo foca na lei ou na legislação e, também, no processo legiferante, como o principal instrumento para se atingir finalidades. Segundo ele, os adeptos da sociological jurisprudence, a começar de Roscoe Pound no início do século XX e mais recentemente Zweigert e Kötz, a lei deve servir à "engenharia social". No entanto, esta intenção instrumental da lei ficou mais evidente nas gestões do Banco Mundial para modificar a legislação e os sistemas jurídicos de países emergentes, sobretudo da América Central, Latina e do Caribe.

A instrumentalização do direito percebido por Castanheira Neves no que ele chama de funcionalismo jurídico vai mais além, muito embora o sentido da instrumentalidade utilizado por Michaels seja o mesmo. Castanheira vê a utilização instrumental do direito pelo funcionalismo numa significação mais ampla. Não seria somente a lei o alvo da instrumentalização. A racionalidade instrumental permearia a realização do direito, especificamente na concatenação decisória judicial. $\mathrm{O}$ juiz substituiria o objetivo justiça por outros não estritamente jurídicos, tais como o econômico, o político e, até mesmo, um sentido meramente sistêmico, na esteira do pensamento de Niklas Luhmann, em que o direito, e no caso a decisão judicial, serviria tão somente como promotora da estabilidade de expectativas contrafáticas.

A perspectiva do funcionalismo jurídico de Castanheira Neves amplia o conceito de funcionalismo, originário das Ciências Sociais, e traz em seu bojo a ideia de instrumentalidade do direito e alteração de seu escopo essencialmente jurídico. Só que a instrumentalidade a que se refere é a do direito servir de instrumento para objetivos diferentes da perspectiva jurídica. Em outras palavras, o valor jurídico construído em torno de concepções como norma jurídica, interpretação jurídica, solução e aplicação jurídicas, são substituídas por objetivos alienígenas, como a economia, a política, o sistema, que tem no direito, e em tudo que dele se depreende e se concebe, apenas um apoio marginal, institucional, valendo-se da aura de legitimidade que ainda detém o direito, para atingir finalidades regulatórias sociais diversas, porque se acredita que o direito perdeu sua função de regulação da sociedade.

O funcionalismo jurídico descrito por Castanheira Neves possui outros ramos e atua em outras áreas de

\footnotetext{
${ }^{47}$ Idem, p. 7.
} 
abrangência do direito. No domínio da inteligibilidade e da práxis humano-social, o funcionalismo jurídico, segundo ele, converteu-se numa verdadeira filosofia social, ao adotar "[...] o ponto de vista da variação contingente de variáveis no quadro complexo de estruturas organizatórias ou de sistemas referíveis, com o objectivo de uma mobilização de possibilidades e meios para uma programação estratégica de fins controláveis pelos efeitos." ${ }^{88}$ Os pressupostos e métodos são os mesmos, mas os objetivos variam de acordo com as intencionalidades últimas em cada uma das modalidades. Assim, é possível ver um funcionalismo jurídico de cariz política, ou econômica, ou de engenharia social, ou até sistêmica. Todos estes, contudo, obedecem a uma programação estratégica de fins controláveis pelos efeitos.

Em nossa tese de doutorado ${ }^{49}$, tivemos a oportunidade de ampliar a observação da incidência do funcionalismo jurídico na prática da prestação jurisdicional. Da nossa perspectiva de análise, verificamos que o controle gerencial e empresarial de produtividade exercido pelo Conselho Nacional de Justiça vem gerando deformações no sistema de julgamento colegiado dos tribunais brasileiros, caracterizando uma funcionalização da Justiça no Brasil, ao se adotar procedimentos de redução das complexidades do julgamento, favorecendo a uniformização da jurisprudência tendente à cem por cento, e o voto por maioria à zero por cento. Estas e outras medidas são respostas até certo ponto lícitas do corpo de julgadores para fazer frente ao volume desmesurado de ações judiciais, cuja entrada não possui controle, senão ainda por via indireta, como fica claro nas novidades procedimentais do atual Código de Processo Civil..$^{50}$

A racionalidade do funcionalismo seria a $Z$ wecrationalität (racionalidade finalística), expressão elaborada por Max Weber, de quem Castanheira lança mão, cuja ação se projeta por meio de “...expectativas postas no comportamento dos objectos do mundo exterior e dos outros homens e mediante a utilização dessas expectativas como 'condições' ou como 'meios' para os próprios fins aspirados ou considerados racionalmente como resultado." ${ }^{51} \mathrm{O}$ funcionalismo quer resultado. Mas que ramo da inteligência jurídica não busca resultado? A diferença está no grau de valor que o funcionalismo deposita sobre o resultado, mais do que outros. Para o funcionalismo jurídico a racionalidade deve desenvolver meios que tragam os resultados de forma mais rápida e direta, afastando tanto quanto possível for as fases do processo de obtenção. Não deixa de ser uma racionalidade do tipo instrumental, denunciada na década de trinta do século passado pela Escola de Frankfurt. ${ }^{52} \mathrm{O}$ objetivo

\footnotetext{
${ }^{48}$ NEVES, António Castanheira. O Direito Hoje e Com Que Sentido?Lisboa: Piaget, 2002, p. 38.

${ }^{49}$ AUTOR. O Funcionalismo Jurídico na Justiça Brasileira. Esboço de uma teoria da funcionalização da razão prática judicial. Tese. 450f. Brasília, 2017. Instituto CEUB de Pesquisa e Desenvolvimento - ICPB. Centro Universitário de Brasília - UNICEUB, 2017.

${ }^{50}$ Conferir, neste caso, o artigo 1.015, do Agravo de Instrumento, cujos casos foram restringidos a doze casos expressos e a outros (XIII) que ainda serão definidos pelo consenso jurisprudencial aos poucos.

${ }^{51}$ Idem, p. 38.

52 "Quanto mais as idéias se tornam automáticas, instrumentalizadas, menos alguém vê nelas pensamentos com um significado próprio. São consideradas como coisas, máquinas. A linguagem tornou-se apenas mais um instrumento no gigantesco aparelho de produção da sociedade moderna." "A verdade e as idéias foram radicalmente funcionalizadas e a linguagem é considerada como um
} 
suplanta o meio e constrói a irracionalidade consumerista.

A ação com base na racionalidade finalística impele o comportamento humano, que "tem o seu fundamento no beneficio ou no prejuízo", a implicar sempre uma vontade que decide por aquilo que lhe é útil, e não por aquilo que possui moralidade, valor, conteúdo axiológico. ${ }^{53}$ No século XIX para o XX surgia na Inglaterra de Jeremy Bentham a proposta de uma bússola da vida econômica, jurídica e política: o Utilitarismo. Baseada na pressuposição de que a ação pública deveria orientar-se pelos instintos humanos, elegeu a felicidade humana como supremo alvo da racionalidade e da prática. Críticas as mais diversas fizeram com que remodelasse sua proposta, surgindo a partir de então o Utilitarismo Negativo, a tentar interromper os fatos que provocam a infelicidade. $\mathrm{O}$ funcionalismo em seu aspecto geral busca o mesmo. O funcionalismo jurídico dá asas a este consumismo imediatista das ações jurídicas. Não se luta mais pelo que é justo, mas sim pelo que se pode beneficiar-se ou para evitar o maior prejuízo possível.

Nesse rumo, Castanheira chama a atenção para as consequências, segundo as quais o funcionalismo exige que a própria prática se converta em técnica, numa intrumentalização da racionalidade, ou no uso da denunciada "razão instrumental", em prol sempre da planificação, programático-regulamentar, privilegiando a eficácia e a eficiência em vez da validade. Em outras palavras, os valores são substituídos pela subjetividade dos fins, e os efeitos, ou a experiência empírica, substituiria os fundamentos. Numa pergunta, pode-se resumir que o funcionalismo e aí também o funcionalismo Jurídico também questionam sempre para que serve o Direito, e não propriamente, o que o Direito é.

Esta estrutura de racionalidade e de ação abriu amplo espaço para a manifestação de um funcionalismo do tipo jurídico, costurado por ampla gama de interesses e objetivos. Para Castanheira, haveria objetivos e interesses políticos, sociais (tecnológicos e econômicos), além de sistêmicos.

\section{OS TIPOS DO FUNCIONALISMO JURÍDICO}

O funcionalismo Jurídico do tipo político assumiria um "directo e determinante objectivo político, com fundamentos e critérios imediatamente políticos. O jurista político assume, antes de tudo, um compromisso ideológico, que orienta uma crítica radical à realidade político-social "numa linha neomarxista com fundamento na utopia, justamente crítico-ideológica, da emancipação". ${ }^{54}$ Como exemplos Castanheira alista o projeto filosófico-social da Escola de Frankfurt, e a particular projeção da "teoria crítica” frankfurtiana pelo Critical Legal

mero instrumento, seja para a estocagem e comunicação dos elementos intelectuais da produção, seja para a orientação das massas." HORKHEIMER, Max. Eclipse da Razão. São Paulo: Centauro, 2002, pp. 30-31.

${ }^{53}$ Idem, p. 39. 
Studies Movement, assim como "o uso alternativo do direito" pelo movimento do Direito Alternativo que, como se sabe, iniciou-se por juristas italianos na década de 70 .

Poder-se-ia incluir aqui o Direito Achado na Rua, de Roberto Lyra Filho, um projeto iniciado na década de sessenta para setenta do século passado, nos corredores da UnB em Brasília. A proposta inicial encontrou desenvolvimento na tese de doutorado de seu aluno, e ex-reitor da Universidade de Brasília, o professor José Geraldo de Souza Júnior, e agora prossegue o caminho de sua evolução pelas mãos e inteligência do professor Doutor Alexandre Bernardino Costa, também da UnB.

A tese de José Geraldo ${ }^{55}$ demonstra a intenção de caracterizar um novo direito, emergente da "rua", ou "espaços públicos", onde imagina, "se dá a formação de sociabilidades reinventadas que permitem abrir a consciência de novos sujeitos para uma cultura de cidadania e de participação democrática.”. Para ele, os sujeitos destes espaços públicos estão algemados e aprisionados em opressões e espoliações, que são condições de sua alienação, e que impedem transformarem seus destinos e suas próprias experiências em direção histórica e emancipadora.

Diz ele, de forma clara, o que supúnhamos ser a intencionalidade da construção teórica. "A tese é resultante de um trabalho simultaneamente político e teórico.". O curso do Direito Achado na Rua, organizado na UnB, busca capacitar assessorias jurídicas dos movimentos sociais a terem por objetivos, entre outros, "determinar o espaço político no qual se desenvolvem as práticas sociais que enunciam direitos ainda que contra legem."; "definir a natureza jurídica do sujeito coletivo capaz de elaborar um projeto político de transformação social e elaborar a sua representação teórica como sujeito coletivo de direito"; "enquadrar os dados derivados destas práticas sociais criadoras de direitos e estabelecer novas categorias jurídicas.".

Parece claro que temos aqui uma intencionalidade genuinamente política, que se encaixa na descrição da análise de Castanheira Neves sobre o funcionalismo do tipo político. Em outras palavras, a intencionalidade é instrumentalizar o direito com fins declaradamente políticos. Isto não significa dizer que o formalismo que ainda vige nas cabeças legislativas e judiciárias deste país não objetive, seja na elaboração normativa, seja na interpretação e aplicação da norma em sua figura abstratamente estabelecida, um projeto apolítico. Mas significa dizer que o direito pelo projeto do Direito Achado na Rua, mais do que nunca, é deliberadamente um projeto político antes de tudo, que entende o direito como mera retórica, e o Judiciário como simples teatro, numa busca de validação política dos interesses e não essencialmente jurídico-democrática.

Mesmo lutando no palco das deliberações jurisdicionais, o projeto do Direito Achado na Rua se vale de argumentos político-sociais, numa clara demonstração de busca de efetivação de direitos que se supõe deixaram

\footnotetext{
${ }^{54}$ NEVES, António Castanheira. O Direito Hoje e Com Que Sentido?Lisboa: Piaget, 2002, p. 42.

${ }^{55} \mathrm{http}: / /$ repositorio.unb.br/bitstream/10482/1401/1/TESE_2008_JoseGeraldoSJunior.pdf.
} 
de ser incluídos no rol da formalista previsão legal do ordenamento jurídico estatuído. A tentativa pela superação do formalismo ou normativismo pelo caminho da argumentação extra-jurídica para que, ao final, jurídica se torne, revela que o direito é simbologia amorfa, e que sua aparência pode ser transformada pelas forças dos interesses políticos mais do que pelos valores intrínsecos e universalizantes que encerram os padrões normativos. Não são mais valores ontológicos previamente estabelecidos, mas valores políticos construídos no momento de sua gênese, que podem ser as lutas pelo reconhecimento de direitos nos espaços sociais, na rua.

Outro ramo do funcionalismo jurídico na percepção teórica de Castanheira Neves encontra-se o funcionalismo do tipo tecnológico-social, por meio de duas sub-modalidades: o tecnológico estrito e o econômico. Em termos gerais, o do tipo social conjuga uma pretensa neutralidade tecnológica com o consequencialismo social. $\mathrm{O}$ modelo persegue objetivos estratégicos, por meio de critérios de funcional performance. $^{56}$

Para ele, o movimento precursor foi a "sociological jurisprudence", associado ao professor de Harvard, Roscoe Pound, com certa afinidade à escola germânica da Interessensjurisprudenz. ${ }^{57} \mathrm{~A}$ base teórica desta escola encontra-se em Ihering e em Bentham. Segundo Castanheira, foi Bentham, mais que Ihering, o que mais influenciou o pensamento de Pound.

O curso teórico se traduziria no princípio fundamental de que "o jurídico, na sua compreensão geral, criação prescritiva e realização concreta, seria determinado (mais geneticamente em Heck, mais funcionalmente em Pound) e teria os seus critérios práticos nos interesses socialmente relevantes." ${ }^{58}$

Um primeiro ponto de partida da teoria é uma menor acentuação da perspectiva do "conflito de interesses" em favor da ideia "de um correlativo equilíbrio ou do maior possível reconhecimento e satisfação global de todos os interesses. Pela fórmula do "the balancing of competing interests"a solução jurídica se daria a partir de uma ponderação de "uma totalizante integração social que superasse a competição inicial.", mais do que simplesmente uma decisão entre os interesses e o interesse social.

O sentido final da "sociological jurisprudence", na interpretação de Castanheira Neves, "era o de que a criação, a interpretação e a aplicação do direito não poderiam realizar-se sem a consideração dos 'social facts', sem o estudo da realidade social relevante. ${ }^{59}$

Para que tal objetivo fosse alcançado, há um grande peso nesta abordagem a investigação sociológica, o que culminou na distinção básica entre interesses individuais, públicos e sociais, que pode melhor ser avaliado no

\footnotetext{
${ }^{56}$ NEVES, António Castanheira. O Direito Hoje e Com Que Sentido? O problema actual da autonomia do direito. Lisboa: Piaget, 2002, p. 43.

${ }^{57}$ NEVES, António Castanheira. Teoria do Direito. Lições proferidas no ano lectivo de 1998/1999. Coimbra: Universidade de Coimbra, 1998, Apontamentos Complementares de Teoria do Direito (Sumários e Textos), p. 3.

${ }^{58}$ idem, p. 3.
} 
texto da Theory of Social Interests, de Pound, onde tentou estabelecer o próprio fundamento e critério da juridicidade. Segundo Pound (An Introduction to the Philosophy of Law) ${ }^{60}$ o pensamento jurídico alterou-se no final do século XIX para o vinte, utilizando-se de um novo método de pensar os problemas jurídicos. Os juristas passaram a encarar as situações jurídicas e as soluções jurisdicionais em termos de necessidades, desejos ou expectativas humanas, ao invés de vontades humanas. O objetivo era harmonizar a satisfação de necessidades e, por isso, cogitaram da finalidade da lei como um máximo de satisfação de necessidades.

Sobre tudo isto, a ideia marcante do funcionalismo tecnológico-social de Roscoe Pound está na ideia do pensamento jurídico como uma "social engineering", com intenção estritamente tecnológica. A intenção jurídica seria substituir a perspectiva normativa, isto é, a consideração da previsão axiologicamente normada em face da consequência prática, pressupondo-se aí uma validade deste itinerário lógico, por um juízo tecnológico social. Isto é, o sistema normativo seria meio para atingir finalidades de eficácia e de eficiência social ou de desenvolvimento social. Para maior clareza ainda, o "direito devia ser concebido e o pensamento jurídico constituído 'como meio de um fim social e como instrumento do desenvolvimento social'”. ${ }^{61}$

O controle social se daria, então, pelo direito, que reconheceria "a correlativa delimitação dos interesses, o equilíbrio dinâmico de todos os tipos de interesses socialmente discrimináveis e relevantes (interesses individuais, públicos e sociais), estabelecendo simultaneamente os meios adequados à garantia desses mesmos interesses assim reconhecidos e delimitados." ${ }^{2}$

Isto exigiria, mais do que se pensava, o envolvimento do jurista por meio de um contato criativo com a realidade social, a qual justificaria, em última instância a tomada de decisão judicial, e não a do formalismo, em suas variáveis (Objetivismo; Originalismo; Textualismo; e Conceptualismo) ${ }^{63}$, com as considerações abstratas e teóricas para justificar uma norma jurídica. Exigiria ainda um sistema jurídico que garantisse mais do que os meros direitos inscritos na Carta Política, mas que positivamente garantisse a realização dos fins sociais.

Este amplo e complexo projeto jurídico significou, para Castanheira Neves, "a intencional superação de uma perspectiva político-social e juridicamente liberal por uma perspectiva orientada já por um compromisso e empenhamento sociais...", em que o direito, na perspectiva de Pound, entraria numa nova fase, a da socialização do

\footnotetext{
${ }^{59}$ Idem, p. 5.

${ }^{60}$ POUND, Roscoe. An Introduction to the Philosophy of Law. EUA: Createspace Pub, 2014, 144 p.

${ }^{61}$ NEVES, António Castanheira. Teoria do Direito. Lições proferidas no ano lectivo de 1998/1999. Coimbra: Universidade de Coimbra, 1998, Apontamentos Complementares de Teoria do Direito (Sumários e Textos), p. 6.

${ }^{62}$ Idem, p. 6.

${ }^{63}$ Thomas Grey. The New Formalism. In: Stanford Public Law and Legal Theory Working Paper Series, no 4, 1999 , p. 2.

"Objetivism: At the most general level, formalists want law to be determinate - to take the form of rules rather than open-ended standards. Originalism: In constitutional law, they favor originalism and reject the idea of a living constitution. Textualism: In dealing with statutes, they favor text-based over purposive interpretation. Conceptualism: When they come to the common law,
} 
direito, ou num "utilitarismo social", com uma intenção de finalismo instrumental do direito para o social. E conclui Castanheira Neves, com as palavras do próprio Roscoe Pound (Sociologia y jurisprudencia), "...as instituições legais e as doutrinas jurídicas constituem os instrumentos de uma forma especializada de controlo social.... ${ }^{64}$

Não mais o controle dos valores implicados nos vários interesses envolvidos em certa questão jurídica, mas o controle das fricções e desgastes sociais através do direito como engenharia social, e "...satisfazer as inumeráveis necessidades humanas com base numa reserva relativamente pequena de bens materiais.". Seria substituir a interpretação jurídica de uma forma política ou idealístico-moral para uma engenharia que seja o meio de uma concreta garantia e realização dos interesses humanos. ${ }^{65}$

Para Castanheira Neves, a proposta deste tipo de funcionalismo jurídico sob a forma de uma engenharia social feita por Pound não teve a necessária base teórica concludente que projetasse um modelo metodicamente eficaz. ${ }^{66}$ Além disto, uma questão prática a esta sugestão teórica é que "os bens materiais dessa existência não são suficientes para todos..." ${ }^{67}$

Posteriormente a Pound, quem deu estrutura metodológica a intenção de uma sociological jurisprudence, segundo Castanheira, foi o juiz Benjamim Cardozo, com os quatro critérios ou "métodos" pelos quais se deviam normativamente determinar as decisões jurídicas concretas, enunciados nas obras The Nature of the Judicial Process, de 1921, e The Growth of the Law, de 1924. Baseado em sua experiência judicante, propôs que o juiz lançasse mão da common law todas as vezes que a lei ou a constituição não fornecesse a regra adequada ao caso em análise, ou o exigível e adequado critério jurídico do caso decidendo.

$\mathrm{Na}$ análise funcionalista da proposta metodológica de Benjamim Cardozo, as implicações, na percepção de Castanheira Neves, ficaram registradas no seguinte estrato:

Neste pensamento, assim sintetizado, não podemos ver já um pensamento jurídico de radical redução sociológica, mas antes um pensamento jurídico normativo de orientação sociológica. O que especifica não é uma redução do jurídico à factualidade social, e sim a tentativa de vencer a indeterminação, que todo o direito vigente revelará na sua realização concreta, mediante uma determinação integrante e evolutivamente reconstrutiva de sentido predominantemente social e que haveria de ser possibilitada já pelo próprio desenvolvimento lógico da juridicidade institucionalizada, já pelo apelo ao ethos socialmente dominante, já pela intenção subordinante e decisiva de um utilitarismo e finalismo sociais de

they prefer to treat abstract categories like contract and tort as coherent structures of concepts and principles, rather than as bodies of sublegislation generated in the course of judicial dispute-resolution."

${ }^{64}$ NEVES, António Castanheira. Teoria do Direito. Lições proferidas no ano lectivo de 1998/1999. Coimbra: Universidade de Coimbra, 1998, Apontamentos Complementares de Teoria do Direito (Sumários e Textos), p. 8

${ }^{65}$ Idem, p. 9.

${ }^{66}$ NEVES, António Castanheira. Teoria do Direito. Lições proferidas no ano lectivo de 1998/1999. Coimbra: Universidade de

Coimbra, 1998, Apontamentos Complementares de Teoria do Direito (Sumários e Textos), p. 10.

${ }^{67}$ Idem, p. 9. 


\section{que o direito haveria de ser instrumento. ${ }^{68}$}

Em anos mais recentes, bem distante dos anos vinte e trinta do século XX em que se manifestou Benjamim Cardozo, nos revela Castanheira a tentativa de redução científico-tecnológica do pensamento jurídico, ou social engineering. As soluções aos problemas jurídicos se dariam pela convocação do direito, mas que por meio deste, como verdadeiro instrumento, oferecesse soluções finalístico-programaticamente mais oportunas ou úteis e instrumentalmente adequadas ou eficazes, de um técnico-sociologismo, abrindo mão das soluções axiológico-normativamente válidas e normativamente fundadas. $\mathrm{O}$ direito serviria a uma programática social, deixando de ser direito, com os valores que dão sentido a sua estrutura normativa.

A função judicante do juiz passaria a ser agora a de engenheiro ou técnico social, com finalidade práticosociais, em que os valores se substituiriam pelos fins subjetivos e os fundamentos normativos pelos efeitos empíricos. Ou seja, uma legitimação pelos efeitos. O direito se converteria numa estratégia político-social funcional e finalisticamente programada, e a decisão concreta como uma tática de realização.

Modelos metódicos para que tal intento se concretizasse, diz Castanheira, já foram dados. Primeiro por Hans Albert ${ }^{69}$, através de uma "prática racional”, inspirado em Karl Popper. Quanto à decisão concreta, o modelo de decisão jurídica de Thomas W. Wälde ${ }^{70}$, resultando na aplicação à decisão jurídica da "teoria da decisão". No que concerne à função judicial, o modelo de juiz tecnocrata - "normativismo tecnocrático", proposto e caracterizado pelo jurista e filósofo belga François Barón Ost ${ }^{71}$, como juge-pacificateur, juge-arbitre, juge entrîneur, por meio de uma "justiça científica”, em que é tida a solução justa aquela mais adequada ao objetivo proposto pelo planificador social, sendo neste caso secundária a consideração de valores materiais ou de regras formais. $^{72}$

Por fim, o funcionalismo tecnológico-social se manifesta numa proposta de instrumentalidade do direito para atender a fins meramente econômicos, como no caso da Law and Economics, que evoluiu para se chegar até a hoje conhecida como Análise Econômica do Direito. Aqui temos a figura inaugural de Ronald Coase e a de Guido Calabrezi, depois a de Pareto, com o "ótimo de Pareto", passando, em nossos dias, pelas propostas do Juiz norte-americano Richard Posner, a de Nicholas Kaldor e John Hicks, chegando até a formulação da chamada Escola de Chicago, cuja proposta da eficiência econômica pela maximização da riqueza social foi contraditada por

\footnotetext{
${ }^{68}$ Idem, p. 19

${ }^{69}$ NEVES, António Castanheira. Teoria do Direito. Lições proferidas no ano lectivo de 1998/1999. Coimbra: Universidade de Coimbra, 1998, Apontamentos Complementares de Teoria do Direito (Sumários e Textos), p. 22.

${ }^{70}$ Idem, p. 25.

${ }^{71}$ OST, François, GÉRARD, Ph, et KERCHOVE, M. van de. Fonction de juger et pouvoir judiciaire. Transformatiions et déplacements. Bruxelles: Publications de Faculté Universitaire Saint-Louis, 1983.

72 NEVES, António Castanheira. Teoria do Direito. Lições proferidas no ano lectivo de 1998/1999. Coimbra: Universidade de Coimbra, 1998, Apontamentos Complementares de Teoria do Direito (Sumários e Textos), p. 28.
} 


\section{Ronald Dworkin. ${ }^{73}$}

Uns dos mais conhecidos expositores da Law and Economics nos revelam em texto de cabeceira de muitos estudantes e propagadores da teoria seus objetivos funcionalistas. Para Robert Cooter e Thomas Ulen ${ }^{74}$ certas perguntas feitas a partir de pressupostos de interesse nitidamente econômicos, tais como "A propriedade privada do espectro eletromagnético vai incentivar seu uso eficiente?", reprogramou o direito ao fornecer uma teoria comportamental para prever como as pessoas reagem às leis e, assim, tornar o processo de elaboração das leis e da jurisprudência mais eficiente para as intencionalidades negociais. O que os preocupa é o impacto que leis e decisões judiciais possam ter sobre o comportamento das pessoas com reflexo econômico, e que poderiam se tornar mais previsíveis. Para os defensores da Law and Economics a palavra "eficiência" deve direcionar as ações e a racionalidade jurídica. Em outras palavras, o valor supremo a nortear o direito é a "eficiência econômica".

Isto tem como pressuposto a eficiência econômica como valor de justiça, sendo que nesta eficiência vige o quadro da distribuição de bens existente no países anglo-saxões de maior mercado consumerista do planeta. Justiça é distribuição de bens. Neste sentido, o direito deve orientar-se a promover meios "legais" e "jurídicos" que favoreçam um "ótimo" de bem-estar econômico. Vê-se por este pequeno excerto do pensamento de teóricos da Law and Economics que sua visão é parcial a respeito da função do direito, e de como sua racionalidade e ação devem ser promovidas. Não são apenas estes aspectos comportamentais humanos que se deve interessar. Logicamente, que ao se analisar os comportamentos humanos a respeito dos quais o direito se dirige haverá implicações econômicas. Mas o direito atinge outros aspectos tão valiosos da vida humana, mais do que simplesmente suas expectativas econômicas. O direito de família, por exemplo, tão importante no equilíbrio psíquico da sociedade, tem como pano de fundo as relações psicoafetivas em grau bem maior que as questões econômicas que também nestas estão envolvidas. Por isto mesmo, neste singelo exemplo, vê-se como o direito vem sendo servido à intencionalidades oportunistas e funcionalistas da atualidade.

Distante totalmente dos dois projetos funcionalistas jurídicos anteriores, Castanheira nos lembra de mais um e, talvez o que mais radicalmente propõe a subversão à subsistência do direito: o funcionalismo sistêmico. Sem maiores incursões, apenas para lembrar, é com Niklas Luhmann, com sua Teoria dos Sistemas, em que o direito é visto simplesmente como um sistema social.75 Como nos adverte Castanheira, "Não se trata já de um sistema no seu sentido tradicional...”....antes de um sistema em que o relevante estará na conjugação...” da unidade material do direito apenas em sentido formal, com uma relação e diferença entre o sistema jurídico e o seu meio exterior ou meio ambiente, graças à qual o sistema garantiria a sua identidade e a sua subsistência perante

\footnotetext{
${ }^{73}$ DWORKIN, Ronald. Uma questão de princípio. São Paulo: Martins Fontes, 2001.

${ }^{74}$ COOTER, Robert; ULEN, Thomas. Direito \& Economia. 5 a edição. Porto Alegre: Bookman, 2010, pp. $24-26$.
} 
este meio exterior. ${ }^{76}$

Em todos estes projetos sobressai-se sempre a intenção de tornar o direito um mero instrumento, uma ferramenta de apoio para o atingimento de outros objetivos - políticos, econômicos, sociais, etc. - que não o propriamente jurídico. $\mathrm{O}$ desencantamento com a razão ${ }^{77}$ jurídica nestes últimos tempos levou a formulações teórico-jurídicas que alteraram a razão de ser do direito e, portanto, é pelo Jurisprudencialismo de Castanheira Neves que se propõe a retomada de um novo ambiente de atuação essencialmente jurídica.

Tal desencantamento com a razão jurídica vem de longe, desde o alvorecer da modernidade, que se mantém em clamor constante pela ausência de evolução do direito, seja pelas instituições com suas estruturas, seja pelo material normativo, seja pela performance jurisdicional. Enfim, todo o universo que envolve o direito e suas múltiplas manifestações, tem se mostrado sempre aquém das expectativas contrafáticas.

Um desencantamento que tem atualmente na objetivação da finalidade explícita, e não tanto sem razão, seu motor de propulsão para empurrar novos caminhos que tornem efetivo e eficaz o direito.

\section{O FUNCIONALISMO JURÍDICO NA JURIDICIDADE BRASILEIRA}

Como último pensamento, e agora numa tentativa de estender estas caracterizações da evolução teórica do direito no século XX e do século XXI para o que pode estar ocorrendo na prática jurídica do Brasil, alude-se à recente reforma do Judiciário no Brasil, mediante a Emenda no 45 à Constituição. No afà de dar efetividade a dois princípios insculpidos em nossa Carta Política, quais sejam, o acesso à Justiça e a celeridade processual, pretendeu o legislador, sob os auspícios de um pensamento democrata, imprimir uma nova postura intencional e novos pressupostos à juridicidade da atividade jurisdicional no Brasil.

A fixação de diretrizes gerenciais, com expectativas nitidamente do tipo empresarial, pois se visa sobretudo a produtividade, e nela se tem a intenção de atingir a satisfação dos objetivos da reforma, vem promovendo pelo menos dois resultados. Um positivo e outro, aparentemente, negativo. O positivo é que os juízes, os tribunais, e todo o aparato do Judiciário brasileiro são permanentemente correicionados e corrigidos, o que vem promovendo uma revolução para melhor no padrão de atendimento às partes, aos procuradores e à sociedade em geral. $\mathrm{O}$ negativo é que uma nova racionalidade, um novo método, um novo objetivo, aparentemente de cunho funcionalista vem se formando, gerando distorções na forma de julgar. A aceleração dos

\footnotetext{
${ }^{75}$ LUHMANN, Niklas. Sociologia do Direito. Volumes I e II. Rio de Janeiro: Tempo Brasileiro, 1983. Law as a Social System. New York: Oxford University Press, 2008.

${ }^{76}$ NEVES, António Castanheira. Teoria do Direito. Lições proferidas no ano lectivo de 1998/1999. Coimbra: Universidade de Coimbra, 1998, Apontamentos Complementares de Teoria do Direito (Sumários e Textos), p. 41.
} 
procedimentos e até a vigilância correicional quanto à análise judicial de todos os itens dos pedidos formulados pelas partes vem provocando novas estratégias dos atores judiciais, que acabam por subverter os objetivos jurisdicionais e os valores aí implicados por meio de uma engenharia estratégica, que talvez a Public Choice e a Theory of Games possam melhor explicar.

A recente promulgação da lei que trouxe a lume o novo código de processo civil também colaborará para este ambiente funcional e policial do funcionamento da Justiça no Brasil, em cuja eficiência operacional tem tomado o lugar da finalidade axiológica embutida no ideal jurídico desde sempre, ao determinar que as ações judiciais terão que, necessariamente, ser apreciadas e julgadas cronologicamente, castrando a liberdade do juiz em melhor administrar os processos sob sua guarda para, acima de tudo, atender ao formalismo funcionalista, agora cristalizado na norma processual civil.

Com esta reforma alia-se recentes tentativas de efetivação ao Judiciário brasileiro. Uma delas, importada do ambiente norte-americano, estende sua compreensão do jurídico já nos cursos avançados de Direito pelo país, a Análise Econômica do Direito. ${ }^{78}$ Trabalhos recentes como o do professor doutor Ivo Gico, do Centro Universitário de Brasília - UniCEUB, com tese defendida na USP, demonstra que as aspirações funcionalistas e utilitaristas ganham espaço de discussão no cenário jurídico brasileiro. Parceiro na mesma academia de Gico, o professor Gustavo Ferreira Ribeiro apresentou juntamente com ele a proposta da AED em recente livro, O Jurista que Calculava, na perspectiva da possibilidade de combinação da abordagem jurídica e econômica para as soluções de problemas jurídicos, tendo em vista que os problemas jurídicos carregam consigo igualmente problemas econômicos.

Partindo do pressuposto que as decisões judiciais implicam em consequências econômicas para as partes, os defensores da aplicação da Análise Econômica do Direito pugnam por uma apreciação conjunta do direito com a economia. $\mathrm{O}$ argumento, num primeiro momento, faz sentido, mas não se faz clara a intenção de tornar a racionalidade jurídica refém das finalidades econômicas. A desconstrução da racionalidade jurídica mantenedora de uma ontologia axiológica do direito, como tenta fazer Richard Posner, ao invocar um pragmatismo de fatos e consequências ${ }^{79}$, parte do pressuposto que "mesmo que a teorização moral possa fornecer um fundamento útil para alguns juízos morais, não deve ser usada para a formulação de juízos jurídicos." ${ }^{80}$

O Brasil vive um curto período de ambiente democrático e ainda parece não saber como melhor administrar os vários interesses, do público ao privado, no campo jurisdicional. As expectativas políticas, sociais e

\footnotetext{
${ }_{77}$ GUIBENTIF, Pierre. Teorias Sociológicas Comparadas e Aplicadas. Bourdieu, Foucault, Habermas e Luhmann face ao Direito. In: Cidades - Comunidades e Territórios, no 14, Lisboa, CET-Centro de Estudos Territoriais (ISCTE), 2007, pp. 89-104.

${ }^{78}$ Cf. COOTER, Robert, e ULEN, Thomas. Direito \& Economia. 5a. ed. Porto Alegre: Artmed, 2010.

${ }^{79}$ POSNER, Richard. A Problemática da Teoria Moral e Jurídica. São Paulo: Martins Fontes, 2012, p. 358.

${ }^{80}$ Idem, p. 4.
} 
econômicas pulsam agora em ritmo mais acelerado. $\mathrm{O}$ que querem os brasileiros, querem imediatamente, e apoiarão aqueles que permitam o acesso ao bem-estar mais rapidamente. Neste rumo o Judiciário é tomado pela avalanche de expectativas imediatistas e foi incluído no processo de atendimento funcional.

As novas ideias teóricas somente fazem sentido se forem pronunciadas por meios estatísticos, na ilusão já vivida pelo mundo desenvolvido da certeza e da ordem das coisas que, agora, como se sabe, é mais imponderável e imprevisível. ${ }^{81} \mathrm{O}$ pacto democrático passa por várias vias, e não somente por uma, por mais atraente que seja. $\mathrm{O}$ direito não se mostra autêntico apenas pelos fins imediatos que por ele se possam atingir, mas também pelo conteúdo de valor, eleito pela sociedade numa consciência jurídica geral, pois implica considerar não somente o interesse individual, mas o coletivo, como ressaltou Castanheira Neves. Com tais elementos de análise em pauta, seria possível considerar pertinente a proposta Jurisprudencialista de António Castanheira Neves, que não despreza os fins, mas os conjuga numa intenção axiológica da juridicidade.

Rodolfo de Camargo Mancuso analisou de forma detida a conjunção de problemas que sitiaram as operações do Judiciário, fazendo com que este, a exemplo da autopoiese sistêmica do direito de Niklas Luhmann, se reinventasse, mas de forma funcionalista, sintetizada na expressão de Mancuso em subtítulo nos seguintes termos: "A investida radical e obsessiva contra a crise numérica dos processos: luta contra a consequência, deixando em aberto a causa". A situação revela um dilema entre a celeridade buscada e a justiça esperada. A questão sobre o equilíbrio desta relação é notória, mas a situação fática do demandismo e da efetiva prestação jurisdicional no Brasil é maior que o questionamento da racionalidade. No afã de dar solução ao problema a impressão do observador deste dilema é que optou-se pela performance, pela produtividade, pela execução de procedimentos mecânicos e administrativamente controlados por meio estatístico, como única forma emergencial de dar satisfação à sociedade e de prover um meio, ainda que débil, de solução.

\section{CONCLUSÃO}

O Jurisprudencialismo de António Castanheira Neves mantém dois fundamentos muito importantes: a lei como fonte inescapável da consideração jurídica, por ser fruto da consciência jurídica histórica de uma comunidade, e a efetiva realização do direito, aplicando-o sempre na perspectiva da preservação do homempessoa, objeto de direito, mas igualmente responsável comunitariamente por deveres. Com isto, mantém hígido a

\footnotetext{
${ }^{81}$ SANTOS, Boaventura de Sousa. A crítica da razão indolente. Contra o desperdício da experiência. São Paulo: Cortez, 2000; PENA-VEJA, Alfredo, e NASCIMENTO, Elimar Pinheiro do (orgs.). O Pensar Complexo. Edgar Morin e a crise da modernidade. Rio de Janeiro: Garamond, 1999. PRIGOGINE, Ilya. O fim das certezas. Tempo, caos e as leis da natureza. São Paulo: Unesp, 1996. CASTELLS, Manuel. A Sociedade em Rede. 10a. ed. São Paulo: Paz e Terra, 2007. Vasta bibliografia há sobre o tema, e a escolha dos representantes neste texto foi aleatória.
} 
autonomia do valor jurídico, sem permitir que descambe para o solipsismo lógico e dedutivo do Normativismo e dos imediatismos e instrumentalismos do Funcionalismo Jurídico, com sua racionalidade própria e solução indiretamente jurídica, de acordo com os objetivos alienígenas que propõe sobre a juridicidade.

O esforço teórico de Castanheira Neves tem, entre outras finalidades, o de prover um referencial razoável à Teoria Geral que impeça o direito de se omitir do mundo real como o Normativismo, e também de tornar as realidades subjacentes do direito e com as quais tenha de tratar como se fossem as que possuíssem um valor substituto ao valor jurídico, tirando do direito o seu lugar de efetivo regulador social e de ciência digna do seu nome, como pretendem as várias faces do Funcionalismo Jurídico apresentadas.

A efetividade da justiça ou a pronta resposta judicial aos embates jurídicos passou a ser mais requerida nestes últimos tempos quando a transparência das informações por meio do imediatismo das comunicações eletrônicas permitiu que mais pessoas pudessem ter, em tempo recorde, uma opinião democrática e conjuntamente direta dos problemas que afligem a comunidade. Isto abalou não somente os empreendimentos privados, com os novos compromissos assumidos perante consumidores, como também as instituições governamentais, que foram surpreendidas com um claro e pronto posicionamento do grupo social, sem a intermediação da imprensa ou do processo eleitoral. A Justiça foi incluída nesta nova dinâmica de participação e teve de reagir ao clamor popular. Como já se disse alhures, tal resposta não se faz somente mediante a adoção do aperfeiçoamento de procedimentos, mas com a refundação de pressupostos que garantam a efetivação da realização do direito. E é por isto que a proposta do Jurisprudencialismo é um caminho oportuno e viável para uma reconstrução do direito no Brasil.

Mesmo assim, parece que o mundo jurídico não se dá conta desta importante opção a ser tomada. A antiga antítese teoria versus prática, originada nos primórdios do período moderno com a iluminação, ainda não foi superada. Não se tem prática de algo se não se sabe ao certo o que praticar. E não se pode teorizar sem que as confabulações não tenham um objetivo de realização prática. São dois lados de uma mesma moeda, não excludentes, mas correlatos. Assim, a efetiva prestação jurisdicional buscada no Brasil desde a reforma do Judiciário iniciada em 2004 passa necessariamente por estes dois caminhos e, um destes, poderia ser o Jurisprudencialismo como solução.

O recente relatório do Justiça em Números produzido recentemente pelo CNJ revela que os esforços meramente procedimentais, relatórios e boas práticas, entre outros, garantem apenas uma arrumação dos móveis velhos na ampla sala do Judiciário, e continuam obsoletos, precisando que novos sejam postos em seu lugar. Enquanto isto não ocorre, decisões judiciais cada vez mais esdrúxulas são tomadas, procedimentos defensivos são erigidos, criando situações teratológicas, alienígenas de teorias do direito superadas, mas ainda não descartadas, a revelar uma contínua desconstrução e uma avançada irracionalidade da estrutura e prática do direito atual. 


\title{
THE JURISPRUDENTIALISM OF ANTONNIO CASTANHEIRA NEVES AND THE LEGAL FUNCTIONALISM
}

\begin{abstract}
The theoretical structure of Jurisprudentialism, proposed by Antônio Castanheira Neves, will be the object of this exhibition. It is a theoretical alternative for the realization of the right nowadays. It is better understood in the face of Legal Normativism and Legal Functionalism, which are the two main dominant legal currents of the general theory of law. The first one was revealed in a rationality anchored in the system of norms and in the logicaldeductive method of interpretation of the system, and the second that seeks to overcome normativist formalism by emphasizing the integral instrumentalization of law with a view to achieving metajuridic ends and greater effectiveness of the system. right. The jurisprudential alternative, in turn, involves the consideration, first, of the human being as a person, who is, at the same time, subject of duty and subject of duties, with responsibilities established in a constructed axiological content. It adds the dimension of praxis, where the individual must always be perceived as a community subject. The juridical problematic is established in this system always with the community axiological conjugation, through established legislation, and the practical universe where historically and culturally the human being is integrated. The conception of Law and the categories of intelligibility of Jurisprudentialism are also exposed. A comparison to Legal Functionalism, current trend identified by Castanheira Neves, is presented as a reinforcement point for his thesis. This presentation is justified by the signs of stress in the current legal system. The methodology used is theoretical-critical through bibliographic analysis. It concludes by the possibility of adoption, or at least discussion, of Jurisprudentialism as a theoretical-juridical assumption in Brazil.
\end{abstract}

Keywords: General Theory of Law - Castanheira Neves - Legal Functionalism - Jurisprudentialism Normativism

\section{REFERENCIAS}

AZEVEDO, Antonio Junqueira de. Caracterização jurídica da dignidade da pessoa humana. In: revista USP, São Paulo, n. 53, p.90-101, março/maio 2002.

BORGES, Ivan Cláudio Pereira. O Funcionalismo Jurídico na Justiça Brasileira. Esboço de uma teoria da funcionalização da razão prática judicial. Tese (Doutorado) 450f. 2017. Instituto CEUB de Pesquisa e Desenvolvimento - ICPD. Centro Universitário de Ensino - CEUB, 2017. 
CASTANHEIRA NEVES, António. O Direito hoje e com Que Sentido? O problema actual da autonomia do direito. Lisboa: Instituto Piaget, 2002.

CASTANHEIRA NEVES, António. O papel do jurista no nosso tempo. In: Digesta. Coimbra: Coimbra Editora, p. 20, 1995.

COOTER, Robert; ULEN, Thomas. Direito \& Economia. 5a edição. Porto Alegre: Bookman, pp. 24-26, 2010.

DWORKIN, Ronald. Uma questão de princípio. São Paulo: Martins Fontes, 2001.

GUIBENTIF, Pierre. Teorias Sociológicas Comparadas e Aplicadas. Bourdieu, Foucault, Habermas e Luhmann face ao Direito. In: Cidades - Comunidades e Territórios, n 14 , Lisboa, CET-Centro de Estudos Territoriais (ISCTE), pp. 89-104, 2007.

HORKHEIMER, Max. Eclipse da Razão. São Paulo: Centauro, 2002, pp. 30-31.

http://repositorio.unb.br/bitstream/10482/1401/1/TESE_2008_JoseGeraldoSJunior.pdf.

LUHMANN, Niklas. Sociologia do Direito. Volumes I e II. Rio de Janeiro: Tempo Brasileiro, 1983. Law as a Social System. New York: Oxford University Press, 2008.

MANCUSO, Rodolfo de Camargo. Acesso à Justiça. Condicionantes Legítimas e Ilegítimas. São Paulo: RT, 2011.

MICHAELS, Ralf. The functionalism of legal origins. 2011. Disponível em: www.ssrn.com. Acesso em: 27 out 2017.

NEVES, António Castanheira. Metodologia Jurídica. Problemas Fundamentais. STVDIA IVRIDICA I, Coimbra: Coimbra Editora, 1993.

NEVES, António Castanheira. O Direito Hoje e Com Que Sentido? Lisboa: Piaget, 2002. 
NEVES, António Castanheira. Teoria do Direito. Lições proferidas no ano lectivo de 1998/1999. Coimbra: Universidade de Coimbra, 1998.

Digesta, Coimbra: Coimbra Editora, 1995, volume 2, III, 2.

Metodologia Jurídica. Problemas Fundamentais. STVDIA IVRIDICA I, Coimbra: Coimbra Editora, 1993; O Direito hoje e com Que Sentido? O problema actual da autonomia do direito. Lisboa: Instituto Piaget, 2002.

A imagem do homem no universo prático. In: Digesta, Coimbra: Coimbra Editora, 1995, vol. 1º pp 311 336. A imagem do homem no universo prático. In: Digesta, Coimbra: Coimbra Editora, 1995, vol. 1º pp. 331332.

NEVES, António Castanheira. Teoria do Direito. Lições proferidas no ano lectivo de 1998/1999. Coimbra: Universidade de Coimbra, 1998.

OST, François, GÉRARD, Ph, et KERCHOVE, M. van de. Fonction de juger et pouvoir judiciaire. Transformatiions et déplacements. Bruxelles: Publications de Faculté Universitaire Saint-Louis, 1983.

ZUMBANSEN, Peer. Law After the Welfare State: Formalism, Functionalism and the Ironic Turn of Reflexive Law. In: Comparative Research in Law \& Political Economy, vol 4, n. ${ }^{\circ}$ 03, p. 14, 13/2008.

POSNER, Richard. A Problemática da Teoria Moral e Jurídica. São Paulo: Martins Fontes, 2012.

POUND, Roscoe. An Introduction to the Philosophy of Law. EUA: Createspace Pub, 2014.

SANTOS, Boaventura de Sousa. A crítica da razão indolente. Contra o desperdício da experiência. São Paulo: Cortez, 2000; PENA-VEJA, Alfredo, e NASCIMENTO, Elimar Pinheiro do (orgs.). O Pensar Complexo. Edgar Morin e a crise da modernidade. Rio de Janeiro: Garamond, 1999. PRIGOGINE, Ilya. O fim das certezas. Tempo, caos e as leis da natureza. São Paulo: Unesp, 1996. CASTELLS, Manuel. A Sociedade em Rede. 10ª ed. São Paulo: Paz e Terra, 2007.

GREY, Thomas. The New Formalism. In: Stanford Public Law and Legal Theory Working Paper Series, no 4, p. 9, 1999. 
WALDRON, Jeremy. Citizenship and Dignity. In: Public Law and Legal Theory Research Paper Series, New York University School of Law. Working Paper 12-74. January 2013.

Trabalho enviado em 29 outubro de 2017

Aceito em 19 de janeiro de 2018 